\title{
Долгожданное продолжение публикации Законодательных актов Петра I Н. А. Воскресенского
}

\section{The Long-Awaited Continuation of the Publication of Nikolai Alekseevich Voskresenskii's The Legislative Acts of Peter I}

\author{
Михаил Киселев \\ Уральский федеральный университет; Институт истории и археологии УрО РАН \\ Mikhail Kiselev \\ Ural Federal University; Institute of History and Archeology, Ural Branch of RAS \\ m.a.kiselev@urfu.ru
}

\begin{abstract}
Рецензия на книгу: Законодательные акты Петра I. Редакции и проекты законов, заметки, доклады, доношения, челобитья и иностранные источники. Сборник документов. В 3 mm. / Сост. Н. А. Воскресенский. T. II: Акты об общественных классах; T. III: Акты о промышленности и торговле / Отв. ред. Е. В. Анисимов; предисл. и подгот. текста Д. О. Серов; археограф. предисл. А. А. Богданов. Москва: Древлехранилище, 2020. 848 с.
\end{abstract}

Review of The Legislative Acts of Peter I. Edited and Drafted Laws, Notes, Reports, Dispatches, Petitions and Foreign Sources. A Collection of Documents in 3 vols. Compiled by Nikolai Alekseevich Voskresenskii. Vol. 2: Social Classes; Vol. 3: Industry and Trade. Gen. ed. by Evgenii Viktorovich Anisimov; foreword and preparation of text by Dmitrii Olegovich Serov; archæographical foreword by Andrei Albertovich Bogdanov. Moscow: Drevlekhranilishche, 2020. 848 p.

Не будет преувеличением сказать, что продолжения публикации Законодательных актов Петра I Николая Алексеевича Воскресенского специалисты по эпохе Петра I ждали едва ли не с 1945 г., когда вышел ее первый том. И вот в 2020 г. благодаря усилиям Д. О. Серова, А. А. Богданова, Е. В. Анисимова и И. И. Федюкина в одной книге был опубликован второй том, заключающий в себе “Акты об общественных классах", и часть третьего тома, заключающая в себе в основном акты о промышленности за 1720-1725 гг. Безусловно, это крайне отрадное и важное событие.

Учитывая, что между деятельностью Н. А. Воскресенского, который работал над книгой в 1920-1940-е гг. и датой ее выхода в свет прошла целая эпоха, данное издание представляет интерес не только как публикация документов петровской эпохи, но и как источник по истории советской исторической науки. Соответственно, в настоящей рецензии будет предпринята попытка обозреть оба этих аспекта.

Издание II-III томов открывается очерком "Н. А. Воскресенский (1889-1948): Опыт начертания судьбы в отблесках эпохи,” написанным Дмитрием Олеговичем Серовым. Д. О. Серов, известный своими работами по эпохе Петра I, еще с конца

\footnotetext{
${ }^{1}$ Работа подготовлена в рамках поддержанного РФФИ научного проекта № 20-09-42022.
} 
200о-х гг. решил заняться биографией Н. А. Воскресенского. В электронном письме от 29 июля 2009 г. Я. А. Лазареву Дмитрий Олегович писал: “Не в ближайшее время, но я твердо настроен подготовить о Н. А. Воскресенском небольшую биографоисториографическую статью. Его вклад в изучение истории государства и права петровского времени воистину неоценим. Может, сложится что-то и опубликовать из его археографического наследия." ${ }^{2}$ же в 2014 г. им была опубликована статья о Воскресенском, ${ }^{3}$ а в 2017 г. под его редакцией была издана монография Воскресенского “Петр Великий как законодатель," которая сопровождалась биографическим очерком об этом советском историке права. ${ }^{4}$ И здесь следует подчеркнуть, что Д. О. Серов отнюдь не воспроизводил один и тот же текст о Воскресенском, он постоянно его дорабатывал, каждый раз привнося в него новые факты. Как результат, получился весьма обстоятельный очерк, в котором довольно подробно излагаются основные факты жизни Воскресенского, а также дается высокая научная оценка как его изысканиям по истории петровского государства и права, так и археографическим приемам, примененным при публикации “Законодательных актов Петра I" (с. XXXVIII-LXXX). ${ }^{5}$ Увы, сам Д. О. Серов, фактически выполнив поставленную еще в 2009 г. им задачу как по изучению биографии Воскресенского, так и по публикации его научного наследия, не дожил до выхода II-III томов, уйдя из жизни 6 октября 2019 г.

В своем очерке Д. О. Серов показывает, как Н. А. Воскресенскому, выпускнику провинциального Нежинского историко-филологического института, который затем работал учителем, было непросто добиться признания как археографа у столичных историков. В итоге Воскресенский получил большее признание и поддержку у историков права в лице Б. И. Сыромятникова, благодаря чему в 1945 г. и вышел первым том “Законодательных актов Петра I.” Однако это издание из-за

\footnotetext{
2 Благодарю Я. А. Лазарева за предоставление копии этого письма. О своих планах заняться биографией Н.А. Воскресенского Д. О. Серов с комментарием - "Из твоего сообщения (и приложения) понял, что ты работал в С[анкт-]П[етер]б[урге] с фондом Воскресенского. Что он представляет собой по составу?” - написал после того, как Я. А. Лазарев при обсуждении одного из сюжетов петровского времени - Дмитрий Олегович был очень отзывчивым человеком, всегда готовым помочь советом и рекомендацией - прислал ему электронную копию нескольких листов рукописей Н. А. Воскресенского, хранившихся в Отделе рукописей РНБ. Эту электронную копию в свою очередь Я. А. Лазарев получил от автора настоящих строк: я ее заказывал во время работы над кандидатской диссертацией о промышленном законодательстве петровского времени (она была защищена в один день и в одном диссертационном совете с докторской диссертацией Д. О. Серова в Уральском государственном университете 26 ноября 2010 г.). Именно в процессе подготовки диссертации у меня возник интерес - как оказалось, едва ли не одновременно с Д. О. Серовым - к научному наследию Н. А. Воскресенского, в результате чего была в 2011 г. опубликована статья об этом историке права. См.: М. А. Киселев, “Н. А. Воскресенский: историк вне корпорации,” в История и историки в пространстве национальной и мировой культуры XVIII-XXI веков, ред. Н. Н. Алеврас, Н. В. Гришина, Ю. В. Краснова (Челябинск: Энциклопедия, 2011), 254-263. (М. A. Kiselev, “N. А. Voskresenskii: istorik vne korporatsii," v Istoriia $i$ istoriki v prostranstve natcionalnoi $i$ mirovoi kultury XVIII-XXI vekov, red. N. N. Alevras, N. V. Grishina, Iu. V. Krasnova (Cheliabinsk: Entsiklopediia, 2011), 254263).

3 D. O. Serov, “Dramatic Destiny of Nikolai Voskresenskiy, a Russian Law Historian,” Quaestio Rossica 1 (2014): 221-240.

4 Д. О. Серов, “Н. А. Воскресенский (1889-1948) - подвижник науки истории русского права,” в Н. А. Воскресенский, Петр Великий как законодатель. Исследование законодательного процесса в России в эпоху реформ первой четверти XVIII века (Москва: Новое литературное обозрение, 2017), 5-58. (D. O. Serov, “N.A. Voskresenskii (1889-1948) - podvizhnik nauki istorii russkogo prava,” v N. A. Voskresenskii, Petr Velikii kak zakonodatel. Issledovanie zakonodatelnogo protsessa $v$ Rossii $v$ epokhu reform pervoi chetverti XVIII veka (Moscow: Novoe literaturnoe obozrenie, 2017), 5-58).

5 Здесь и далее страницы издания указываются непосредственно в тексте.
} 
археографических приемов Воскресенского в 1946 г. было подвергнуто довольно жесткой критике на страницах главного советского исторического журнала “Вопросы истории” учеником А. С. Лаппо-Данилевского и одним из ведущих специалистов по археографии Александром Игнатьевичем Андреевым, под руководством которого в это время велась подготовка "Писем и бумаг Петра Великого.” Комментируя критику Андреева, Д. О. Серов отмечает, что Александр Игнатьевич фактически не смог уловить логику Воскресенского “в его археографических приемах (а они ни в коей мере не были ни абсурдными, ни антинаучными, просто не во всем соответствовали публикаторским канонам, сформировавшимся в 1900-х - 1910-х гг.)." И не без некоторой доли справедливости Д. О. Серов утверждает, что в случае с Воскресенским “Александр Андреев повел себя как жесткий догматик от археографии, органически не способный к восприятию какой-либо альтернативной точки зрения” (с. LXXII-LXXIII). ${ }^{6}$ В связи с этим заметим, что современной социологии хорошо известна неравномерность распределения признания в среде ученых (вспомним “эффект Матфея” Р. Мертона), так что в определенной степени биография Воскресенского является еще одной иллюстрацией того, как ученым с научной “периферии” непросто добиться хорошей позиции в пространстве науки.

Однако Д. О. Серов не ограничивается фактом критики Н. А. Воскресенского А. И. Андреевым и изображает последнего едва ли не главным виновником всех бед Воскресенского на протяжении 1920-1940-х гг. с небольшим перерывом: пока Александр Игнатьевич, арестованный по “Академическому делу," “пребывал в 'Крестах'," а затем в Красноярском крае эту линию его деятельности подхватили выученики М. Н. Покровского, которые (хотя и по совершенно иным мотивам) “перекрывали кислород” Н. А. Воскресенскому в первой половине 1930-х гг." Соответственно, Дмитрий Олегович возлагает вину на Андреева в том, что Воскресенский во второй половине 1940-х гг. не смог опубликовать второй том “Законодательных актов Петра I” (с. LXXII-LXXIII).

Отметим, что вывод о неблаговидной роли А. И. Андреева в судьбе Н. А. Воскресенского был сделан Д. О. Серовым без обращения к хранящемуся в Санктпетербургском филиале Архива РАН весьма объемному фонду Андреева, насчитывающему почти полторы тысячи единиц хранения. Автор настоящих строк последний раз беседовал с Дмитрием Олеговичем в РГАДА в начале июня 2019 г., и разговор шел как раз об очерке о Н. А. Воскресенском для рецензируемого издания. Сам Д. О. Серов в разговоре признавал, что ему не удалось поработать с фондом Андреева. Тем не менее, он был уверен в своих выводах.

Однако обращение к документам из фонда А. И. Андреева, где хранятся письма к Андрееву самого Н. А. Воскресенского, его супруги Зинаиды Андреевны, а также других историков, в которых содержится подчас уникальная информация о Воскресенском, заставляет пересмотреть изложенную Д. О. Серовым историю.

Прежде всего, к 1941 г. сам Н. А. Воскресенский не считал А. И. Андреева своим гонителем и вел с ним деловую переписку, в которой даже делился творческими

\footnotetext{
${ }^{6}$ Ср. с нашими выводами 2011 г.: “Н. А. Воскресенский со своим проектом был определен А. И. Андреевым вне развивавшейся научной традиции. [...] Воскресенский не успел закрепиться в историческом научном сообществе, которое переживало непростые трансформации, и после ареста и ссылки С. Ф. Платонова находился в научной изоляции. Его научные замыслы оказались проектами одиночки, которые осуществлялись в свободное от основной работы время. Поддержка, оказанная ему Б. И. Сыромятниковым, пришлась уже на завершающие стадии проекта и была крайне осложнена войной” (Киселев, “Н. А. Воскресенский,” 26o). (Kiselev, “N. A. Voskresenskii,” 26o).
} 
планами. Так, в письме от 27 мая 1941 г. он сообщал Андрееву: “Правление корректур уже мною заканчивается. Набран полностью первый том в $6 о 0$ страниц. Издано будет тщательно и даже художественно. Печатание т. I Законод[ательных] актов будет закончено через два месяца. Я надеюсь, он будет большим вкладом и в историю Петра, и в палеографию и в археографию. Меня интересует Ваше мнение о книге, когда она выйдет в свет. [...] Лето проведу в Москве за подготовкой 4 тома и проверкой $3^{\text {го }}$. Осенью закончу диссертацию на доктора: 'Петр Великий, как законодатель' и думаю защищать в Московском Университете."

Далее, не выдерживают критики и рассуждения об “ударах," которые А. И. Андреев якобы наносил Н. А. Воскресенскому после 1941 г. Так, Д. О. Серов пишет: “Для начала, будучи ответственным редактором многотомника Письма и бумаги Петра Великого, А. И. Андреев, судя по всему, фактически отстранил Николая Воскресенского от участия в рабочей группе по его подготовке (в которую Николай Алексеевич был включен [...] в 1943 г.).” По мнению Дмитрия Олеговича, “состоявшийся в июне 1946 г. выход в свет второго выпуска 7-го тома Писем и бумаг [...] явился [...] воодушевляющим событием” для Николая Алексеевича, “однако имя Николая Воскресенского в числе составителей второго выпуска, увы, не значилось” (с. LXXIII). Итак, у читателя складывается впечатление, что Андреев совершил по отношению к Воскресенскому неэтичный административный поступок, отстранив от работы над Письмами и бумагами Петра Великого и даже не упомянув вклада Воскресенского в подготовку этого издания.

Однако, судя по всему, ситуация была иной. Действительно, 3 июня 1943 г. корреспондент Известий со слов А. М. Панкратовой сообщил в газете, что "сейчас организована постоянная комиссия по изучению эпохи Петра I. Комиссия объединит всю исследовательскую работу в этой области.” Отметив, что к работе комиссии привлечен и Н. А. Воскресенский, корреспондент писал, что “Воскресенский многие годы своей жизни посвятил работе по подготовке и изданию документов по истории государственной деятельности Петра I. Тов. Воскресенский обнаружил в ряде архивов множество петровских бумаг автографов, никем ранее не использованных.” 8 В то же время, как следует из писем А. И. Андрееву от К. Н. Сербиной, которая в это время фактически руководила Ленинградским отделением Института истории АН СССР (ЛОИИ), весной-летом 1943 г. Воскресенский вел переговоры с Панкратовой о трудоустройстве в ЛОИИ младшим научным сотрудником, а также о возможности публикации Институтом истории его “Законодательных актов Петра I.” Тем не менее, ни трудоустройство, ни публикация не состоялись. Это было связано с Б. И. Сыромятниковым, который смог предложить Воскресенскому лучшие условия. ${ }^{9}$ Как результат, Воскресенский с 1 сентября 1943 г. стал старшим научным сотрудником в Институт права АН СССР, а Сыромятников попытался устроить ему получение степени доктора юридических наук, минуя защиту кандидатской диссертации. Правда, этого не получилось, так что по результатам защиты, состоявшейся в Институте права 21 июля 1944 г., Воскресенскому была присвоена только ученая степень кандидата юридических

\footnotetext{
${ }^{7}$ Санкт-петербургский филиал Архива Российской академии наук (далее - СПФ АРАН), ф. 934, оп. 5, д. 108, л. 2 об.-3 (Sankt-Peterburgskii filial Arkhiva Rossiiskoi akademii nauk (dalee - SPF ARAN), f. 934, op. 5, d. 108, 1. 2 ob.-3).

8 “Новые публикации документов Петра I," Известия, 3 июня, 1943, 4. (“Novye publikatsii dokumentov Petra I," Izvestiia, 3 iiunia, 1943, 4)

${ }^{9}$ СПФ АРАН, ф. 934, оп. 5, д. 311, л. 92 об.-93 об., 99, 104. (SPF ARAN, f. 934, op. 5, d. 311, 1. 92 ob.-93 ob., 99, 104).
} 
наук. Таким образом, Воскресенский не принимал участия в подготовке Писем $u$ бумаг Петра Великого отнюдь не потому, что его отстранил от этого Андреев, а потому, что Николай Алексеевич выбрал в итоге в качестве места работы Институт права, а не Институт истории.

В связи с этим отметим, что письма К. Н. Сербиной содержат весьма интересные сведения о действительно непростых взаимоотношениях А. И. Андреева и Н. А. Воскресенского. Так, она 2 марта 1944 г. написала Андрееву: "Что вы сделали Н. А. В[оскресе]нскому, он рвет и мечет и называет Вас “грековцем," что в его устах явл[яется] наивысшей степенью ненависти. Видимо, дело в том, что Вы отказались дать положительный отзыв на его работу. Пыталась убедить его в том, что обвинять Вас в приверженности Б. Д. [Грекову] никак не возможно, но Н. А. твердо стоит на своем.” ${ }^{\prime \prime}$ Кроме того, 1 апреля 1944 г. Сербина сообщила Андрееву следующее о результатах разговоров с Воскресенским: "Я сообщила ему о том, что его диссертация снова попала к Вам и о результатах Ваших разговоров с Б. Д. [Грековым]. Первое сообщение его обрадовало, второе огорчило, т. к. Вас он очень уважает как человека и высоко расценивает как ученого, поэтому ему очень приятно, что Вы будете его оппонентом. Причастность же к этому делу Б. Д. огорчает его, т. к. Б. Д. он не любит, не уважает и не считает за ученого. О нем он говорит, что у 'Б. Д. одно лишь качество - святость.' Б. Д. действует на него как кумач на быка. Пожалуйста, не выдавайте меня, не гов[орите] Н. А., что Вы от меня узнали о том, что он считает Вас 'грековцем,' а то он перестанет доверять мне за то, что я выболталась. Н. А. просил меня узнать у Вас, кто такая Айнберг, спец[иалист] по археографии, ей также (по словам Н. А.) поручено сделать рецензию на работу Н. А. Это просто убивает Н. А., т. к. она принадлежит к национ[альности], кот[орую] он крайне не любит."

Итак, Н. А. Воскресенский весьма уважал А. И. Андреева как человека и высоко ценил как ученого, хотя ему была крайне неприятна его критика. Гонителем же своим Николай Алексеевич считал академика Б. Д. Грекова. Об этом, кстати, свидетельствовали и письма самого Воскресенского. Последний в письме Б. И. Сыромятникову от 12 августа 1946 г. заявлял, что “в течение десятилетий Гр[ек]ов, преследуя меня и мои работы (выделено нами. - М. К.), достиг того, что я сейчас не имею сил бороться и сражаться за свое дело.” В другом письме - от 19 сентября - Николай Алексеевич делился с Сыромятниковым таким планом: “Я намерен написать все-таки Историю одного труда, в частности об отношении Гр[екова] и его приспешников к моим работам; это будет повествование и о личном деле и по существу о деятельности Ин[ститу]та Истории." Что же до критической рецензии А. И. Андреева на первый том Законодательных актов Петра I, вышедшей в Bonpocax истории, то Воскресенский написал следующее: "Конечно, следовало бы возразить на критику Андреева, но мне сейчас это строжайше воспрещено. Придется пока 'ответствовать молчанием'."'2 Получается, что если к Грекову Воскресенский испытывал едва ли не ненависть, то с Андреевым он считал

\footnotetext{
${ }^{10}$ СПФ АРАН, ф. 934, оп. 5, д. 311, л. 146 об. (SPF ARAN, f. 934, op. 5, d. 311, 1. 146 оb.).

${ }^{11}$ СПФ АРАН, ф. 934, оп. 5, д. 311, л. 150 об. (SPF ARAN, f. 934, op. 5, d. 311, 1. 150 оb.). С. Ф. Айнберг, еврейка по национальности, была ученицей С. Ф. Платонова. Она окончила в 1911 г. историкофилологический факультет Высших женских Бестужевских курсов.

${ }^{12}$ Отдел рукописей Российской государственной библиотеки (далее - ОР РГБ), ф. 366, к. 37, д. 41, л. 4, 5 об., 7. (Otdel rukopisei Rossiiskoi gosudarstvennoi biblioteki (dalee - OR RGB), f. 366, k. 37, d. 41, 1. 4, 5 ob., 7).
} 
возможным вести научную дискуссию. Кстати, письма Воскресенского Сыромятникову были известны Дмитрию Олеговичу, однако он почему-то в своем очерке решил не упоминать о претензиях Воскресенского к Грекову. ${ }^{13}$ Иное дело, что можно только догадываться, насколько именно Греков был виновником всех бедствий Воскресенского и не было ли это некоего рода манией последнего?

В целом же необходимо признать, что Д. О. Серов не смог привести каких-либо подтверждаемых источниками сведений, что именно А. И. Андреев как-то пытался - на административном уровне - вредить Н. А. Воскресенскому. И здесь можно снова упомянуть тяжкое обвинение, предъявленное А. И. Андрееву: последний, "не сумев воспрепятствовать [...] публикации первого тома Законодательных актов Петра I,” каким-то образом “отыгрался' на томе втором.” Именно с этим Д. О. Серов увязал факт, что рукопись второго тома оказалась “в библиотеке именно Института истории" (с. LXXIII).

Прежде всего, укажем, что Д. О. Серов не привел каких-либо документов, объясняющих, как А. И. Андреев, будучи сотрудником Института истории, находившегося в ведении Отделения истории и философии АН СССР, смог как-то воспрепятствовать издательским планам Института права, бывшего в ведении Отделения права и экономики АН СССР. Все же стоит понимать, что одно - личная неприязнь, и другое - наличие административной возможности для реализации неприязни. В реалиях того времени возможность вторгнуться в планы другого института, находившегося в другом отделении, едва ли была даже у академика Б. Д. Грекова, не говоря о сотрудниках его института.

И вот здесь становится важным понимание идеологического контекста позднего сталинизма, который, к сожалению, полностью проигнорировал в своем очерке Д. О.Серов. А этот контекст имел самое непосредственное отношение к судьбе Н.А. Воскресенского и его трудов. Дело в том, что именно летом 1946 г. в общественных науках, включая и правоведение, началась большая идеологическая кампания по критике и самокритике, известная как “ждановщина.” Одним из ключевых инструментов по руководству этой кампании была специально созданная газета Культура и жизнь, издававшаяся Агитпропом ЦК ВКП(б). В этой газете 20 июля 1946 г. была опубликована статья, где критиковался Институт права АН СССР, при этом одной из главных мишеней из-за своей книги 1943 г. “Регулярное' государство Петра I и его идеология” стал покровительствовавший Воскресенскому Б. И. Сыромятников. Последний за свою книгу получил порцию критики еще в 1944 г. на страницах журнала ЦК ВКП(б) Большевик. Зачинатели “ждановщины” в правоведении припомнили Сыромятникову его недавние идеологические прегрешения, по касательной зацепляя и первый том Н. А. Воскресенского, редактором которого был как раз Сыромятников:

13 Весьма примечательно, что Д. О. Серов процитировал письмо Н. А. Воскресенского Б. И. Сыромятникову от 12 августа 1946 г., убрав из него упоминание Б. Д. Грекова: "Николай Воскресенский скупо упомянул о голоде, который едва не ‘погубил меня и мою семью [...] во время блокады” (с. LVI). Однако в письме Воскресенского его не просто губил голод. Голодом его губил Б. Д. Греков и его “приспешники”: “Когда Вы (Б. И. Сыромятников. - М. К.) совсем поправитесь, я осмелюсь напомнить и о своей работе; может быть, Вы найдете немного времени и достаточно сил, чтобы просмотреть ее до конца и высказать свое мнение о ней. Ваше мнение для меня принципиально важно и исключительно авторитетно, и я Вам буду весьма признателен. Это мнение, я думаю, до сих пор и в дальнейшем будет противоположно мнению Гр[екова]ва и его приспешников. Он и они, в связи с временными условиями, которые переживала Россия, погубили меня и мою семью голодом во время блокады, так как задержали мои работы и препятствовали их напечатанию” (OP РГБ, ф. 366, к. 37, д. 41, л. 3-2 об.). (OR RGB, f. 366, k. 37, d. 41, l. 3-2 ob.). 
В 1945 г. Институт права выпустил книгу Н. А. Воскресенского Законодательные акты Петра I, т.1, с предисловием проф. Сыромятникова. В этом предисловии повторяются старые ошибки автора, вновь заявляющего об антифеодальных, антидворянских тенденциях в законодательстве Петра Первого. [...] Система замалчивания ошибок и недостатков научной работы, атмосфера благодушия и самоуспокоенности, царящая в Институте права, не могут способствовать успехам науки. ${ }^{14}$

В Институте права АН СССР довольно быстро отреагировали на критику страницах Культуры и жизни. 19 сентября 1946 г. состоялось закрытое партсобрание Института, на котором его директор, старый большевик и академик И. П. Трайнин прямо заявил: “Нужно признать, что и у нас были тенденции уйти в историю от действительности. У нас был сектор истории права, который занимался и Киевской Русью, Петром I и т. д. Предоставим это дело Институту Истории. Нам нужно в качестве первоочередной задачи в области истории - XIX и XX в. и история советского государства и права." ${ }^{\prime 5}$ Далее, 23 сентября состоялось заседание ученого совета Института, на котором тот же Трайнин сделал схожее заявление: "У нас был сектор истории права, который занимался вопросами Киевской Руси и главным образом Петром І. Мы его ликвидировали, но это не значит, что вообще мы думаем отказаться от истории. Мы считаем, однако, что эта история должна быть приближена к современным запросам. Если мы сейчас будем заниматься XIX веком, а все остальное отдадим Институту Истории, то от этого только выиграем." ${ }^{\prime 6}$ Кроме того, передовица октябрьского номера институтского журнала Советское государство и право - в духе самокритики - извещала читателей: “Ошибочная концепция проф. Сыромятникова нашла свое отражение и в книге Н. А. Воскресенского Законодательные акты Петра I."

Итак, под влиянием разгромной статьи в Культуре и жизни дирекция Института права АН СССР признала, что в публикации Н. А. Воскресенского получили отражение “ошибочные” взгляды Б. И. Сыромятникова, а также фактически прикрыло в Институте изучение истории русского государства и права до XIX века. В этом отношении становится понятным, почему Воскресенского, как это установил в своем очерке Д. О. Серов, приказом от 11 октября уволили из Института с 1 ноября 1946 г. (с. LXXIV). Для Института права продолжение публикации Законодательных актов Петра I было не просто неактуальной затеей, это было уже идеологически опасным мероприятием. Соответственно, второй том Воскресенского не вышел не из-за неких козней А. И. Андреева. И книга, и сам Николай Алексеевич оказались одними из первых жертв “ждановщины” в советском правоведении. Другими жертвами “ждановщины," только уже в 1948 г., станут Андреев и редактируемый им сборник Петр Великий.

Как же тогда второй том, на основании которого и была сделана часть настоящей публикации, оказался в архиве Института истории АН СССР? Здесь может помочь человек, знавший Н. А. Воскресенского, пожалуй, лучше всех, - его супруга Зинаида

\footnotetext{
${ }^{14}$ Л. Кузьмин, Г. Калинин, “В стороне от актуальных проблем,” Культура и жизнь, 20 июля, 1946, 3. (L. Kuz'min, G. Kalinin, “V storone ot aktualnykh problem," Kul'tura i zhizn', 20 iiulia, 1946, 3).

${ }^{15}$ Центральный государственный архив города Москвы, ф. П-228, оп. 1, д. 5, л. 168. (Tsentral'nyi gosudarstvennyi arkhiv goroda Moskvy, f. P-228, op. 1, d. 5, 1. 168).

${ }^{16}$ Архив Российской академии наук (далее - АРАН), ф. 499, оп. 1, д. 70, л. 150 об.-151 об. (Arkhiv Rossiiskoi akademii nauk (dalee- ARAN), f. 499, op. 1, d. 70, 1. 150 ob.-151 ob.).

17 “Перед важными и ответственными задачами," Советское государство и право, 10 (1946), 4. ("Pered vazhnymi i otvetstvennymi zadachami," Sovetskoe gosudarstvo i pravo, 10 (1946), 4).
} 
Андреевна. Она писала А. И. Андрееву 12 сентября 1948 г.: “От Руфи Иосифовны Козинцевой я узнала о Вашем добром участии к памяти Н[иколая] А[лексеевича] и к судьбе его библиотеки и рукописей”. Далее она обращалась с просьбой: “Пропали 2 книги III тома О пром[ышленности] и торговле, а серединная книга есть. М. П. Сыромятникова (вдова Б. И. Сыромятникова. - М. К.) обещала поискать среди книг Бориса Ивановича, но еще не нашла. Не брал ли их на время Кафенгауз? Не могли ли бы Вы дипломатично узнать?" 8 Кроме того, сохранилось письмо от Р. И. Козинцевой Андрееву от 19 декабря 1948 г., где она писала: “Получила от Воскресенской открытку, датированную 19 X [...] Она пишет, что к ней приезжала по поручению Б. Д. Г[рекова] Т. Крылова по поводу материалов Воскр[есенско]го. Известно ли это Вам?"'19 Как видно из этих сведений, во второй половине 1948 г. Институт истории АН СССР, оказавшийся в это время под идеологическим ударом, проявлял интерес к рукописям Воскресенского, а вдова последнего была благодарна Андрееву за участие в решении их судьбы. Вполне возможно, что историки, включая Андреева, видя, что в условиях “ждановщины” наследие Воскресенского оказалось неактуальным для правоведов и, соответственно, было под угрозой, участвовали в его спасении. И, похоже, именно благодаря такому интересу со стороны историков второй том Законодательных актов Петра I, уже ненужный в Институте права АН СССР, оказался в архиве Института истории. На это, кстати, указывает и то, что второй том, согласно археографическому предисловию А. А. Богданова к настоящему изданию, поступил в институтский архив в 1951 г. “из сектора истории СССР до XIX века Института” (с. LXXXIII).

В конце концов, одно дело - это вести сугубо научные споры о тонкостях археографии, и другое - оказаться под ударом репрессивной машины. Стоит полагать, что А. И. Андреев, испытавший в советское время арест и ссылку по “Академическому делу”, а также переживший, как и Н. А. Воскресенский, первую блокадную зиму, ${ }^{20}$ прекрасно это понимал и был готов, отложив научные споры, помочь в условиях новой идеологической кампании. Таким образом, все же следует признать, что квалификация Андреева как главного гонителя Воскресенского не соответствует исторической действительности и является ошибочной. Они оба, как и их научные труды, были жертвами идеологической системы сталинизма. Правда, это не отменяет факта критики Андреевым Воскресенского как археографа, и в вопросе, кто из них прав, не столь просто разобраться.

В связи с этим перейдем к проблеме археографии публикации II-III томов. После очерка Д. О. Серова в книге помещено краткое археографическое предисловие А. А. Богданова, в котором описываются рукописи, положенные в основу издания. Еще в 1946 г. Б. И. Сыромятников, пытаясь защититься от критики газеты Культура u

\footnotetext{
${ }^{18}$ СПФ АРАН, ф. 934, оп. 5, д. 107, л. 2 об. (SPF ARAN, f. 934, op. 5, d. 107, 1. 2 оb.).

${ }^{19}$ СПФ АРАН, ф. 934, оп. 5, д. 192, л. 4. (SPF ARAN, f. 934, оp. 5, d. 192, 1. 4).

${ }^{20}$ Сохранились письма А. И. Андреева из блокадного Ленинграда президенту АН СССР С. И. Вавилову. 18 ноября 1941 г. Андреев сообщил Вавилову: “12-го я лишился своей комнаты (во дворе дома упала бомба и от волны пострадал наш дом)”. 15 марта 1942 г., пережив блокадную зиму, Андреев писал Вавилову: "Все мы страшно изменились; перемены приходят резкие после желуд[очных] заболеваний (голодный колит, дезинтерия и др.), которые нередки здесь; мы с женой перенесли одну из этих прелестей в февр[але], и, вернувшись к работе, меня многие не узнавали [...] Работа учреждений научных, конечно проходит в беседах и разговорах на продовольств[енные] темы: все вертится около хлеба [...] И несмотря на все это в ряде акад[емических] учреждений, где все же остаются еще живые и не уехавшие люди [...] заметны [...] намерения с первым теплом продолжать научные работы" (АРAH, ф. 596, оп. 3, д. 103, л. 4, 7 об.-8). (ARAN, f. 596, op. 3, d. 103, 1. 4, 7 ob.-8).
} 
жизнь, заявил в письме в редакцию: “Монументальное издание актов Петра I Н. Воскресенского, составляющие обширное собрание впервые публикуемых драгоценных материалов, послужило мне основной базой для моих построений. Наиболее ценные данные собраны Воскресенским во втором и третьем томах, посвященных социальному и экономическому законодательству и политике Петра I. Все три тома хранятся в Институте права Академии Наук в образцовом виде (последние два подготовлены к печати)."21 Однако к настоящему времени в полном виде известен только второй том в редакции 1942 г. (находится в архиве Института российской истории РАН), в то время как у третьего тома в редакции 1943 г. сохранилась только вторая книга, содержащая акты о промышленности за 1720-1725 гг., а также Берг-привилегию 1719 г. и связанное с ней описание шведской Бергколлегии 1718 г. (хранится в Отделе рукописей РНБ). Соответственно, в предисловии А. А. Богдановым дается описание этих рукописей. Кроме того, историком отмечается, что в Отделе рукописей РНБ сохранилась редакция 1938 г. актов о промышленности и торговле, а также в непереплетенном виде в редакции 1947 г. акты о торговле, которые в итоге должны были составить третью книгу третьего тома. И далее сообщается, что если второй том публикуется полностью, то у третьего - только “срединная” книга редакции 1943 г. (с. LXXXII-LXXXIII). В решении опубликовать только эту часть есть своя логика. Однако акты о промышленности до 1720 г., найденные Н. А. Воскресенским и затем помещенные в редакцию 1938 г. (общим числом около 170), также обладают существенной научной значимостью, равно как и акты о торговле из редакции 1947 г. На наш взгляд, имело смысл готовить третий том к публикации отдельно, поместив в него как “срединную” часть 1943 г., так и в качестве условного приложения акты из редакции 1938 и 1947 г. С учетом этого можно сказать, что история с публикацией археографического наследия Н. А. Воскресенского еще не завершена.

Далее, надлежит отметить, что во вводных статьях публикаторов книги специально не оговорено, как велась подготовка II-III томов к изданию, вносились ли какие-либо изменения в публикацию актов по сравнению с подходом Н. А. Воскресенского. Отметим, что Воскресенский первоначально изложил свои правила передачи архивных документов при издании Законодательных актов Петра I в 1925 г., а затем развил их в “Археографических введениях" к первому и второму томам своей публикации. Главным образцом применения им этих правил является опубликованный в 1945 г. под его контролем первый том Законодательных актов Петра I. Соответственно, всем этим следовало бы руководствоваться при продолжении публикации. Однако при ознакомлении непосредственно с текстами, вошедшими в состав издания 2020 г., с последующей их сверкой как с правилами Воскресенского, так и с рукописью второго тома, которая была положена в основу издания, становится понятно, что было внесено ряд изменений.

1. Прежде всего, Н. А. Воскресенский придавал особое значение “собственноручным писаниям" Петра I и заявлял: "Все, написанное Петром Великим, может занимать исключительное положение: оно должно быть передано точно, с соблюдением всех особенностей его правописания, за исключением расстановки знаков и помещения подстрочных букв в строку."22 Для Воскресенского

\footnotetext{
${ }^{21}$ ОР РГБ, ф. 366, к. 37, д. 11, л. 4. (OR RGB, f. 366, k. 37, d. 11, 1. 4).

22 "Приемы научного издания памятников законодательства Петра Великого. Тезисы к докладу Н.

А. Воскресенского," в Летопись занятий археографической комиссии за 1923-1925 годы (Ленинград: AН СССР, 1926), вып. 33, 62. ("Priemy nauchnogo izdaniia pamiatnikov zakonodatel'stva Petra Velikogo.
} 
было принципиально опубликовать все, что собственноручно написал Петр. В связи с этим даже в тех случаях, когда черновой проект законодательного акта, написанный монархом, имел незначительные отличия от белового текста, переписанного писцом и только подписанного Петром, Воскресенский полностью приводил черновой проект. Так, например, он поступил в первом томе с указами, связанными с созданием Сената в 1711 г., за что, помимо прочего, был подвергнут критике А. И. Андреевым: “Черновики и беловики документов печатаются обычно один за другим (см., например, №№ 241-244), хотя иногда они отличаются только мелочами, которые можно бы отметить в построчных примечаниях."23

Издание 2020 г. в вопросе о полном воспроизводстве черновика при незначительных расхождениях с беловиком по факту следует рекомендации А. И. Андреева. Так, при воспроизводстве акта № 89 в текстуальном примечании с пометой “Примеч. публикатора" написано, что "в рукописи Н. А. Воскресенского приведен черновой и беловой текст документа.” Соответственно, был дан только беловик, а в подстрочных ссылках были приведены разночтения с черновиком, написанным рукою Петра I (с. 86). Схожим образом в издании 2020 г. поступили с актами № 12, 23, 85, 89, 166, 206, 29 (362) (с. 17, 24, 84, 86, 171, 214, 483). При этом, как показывает обращение к рукописи Воскресенского, не во всех случаях в текстуальных примечаниях оговаривается, что это именно решение публикатора, а не Воскресенского. По крайней мере, это фиксируется в случае воспроизводства акта № 33 (с. 28-29). ${ }^{24}$

2. Касательно публикации акта, у которого было несколько редакций, Н. А. Воскресенский в 1925 г. предлагал, что “первая и последняя редакции должны быть полностью, а из промежуточных редакций [...] могут быть приведены только главы и пункты, содержащие изменение норм." ${ }^{25}$ При издании первого тома Воскресенский отмечал, что им “приводился большею частью первоначальный проект полностью, средние же редакции - только в изменениях содержания самых норм, и, наконец, последняя редакция - закон - всегда полно и без сокращений." 6 Однако в издании 2020 г. для знаменитого петровского указа о единонаследии от 24 марта 1714 г. (№ 5, 6-10) привели только текст закона. Что же до набросков отдельных частей, сделанных рукой Петра, а также первой редакции закона, которые Воскресенский воспроизвел в рукописи, то их не издали, приведя лишь в текстуальных примечаниях разночтения (с. 10-16). Схожим образом, т.е. без

Tezisy k dokladu N. A. Voskresenskogo," v Letopis zaniatii arkheograficheskoi komissii za 1923-1925 gody (Leningrad: AN SSSR, 1926). vyp. 33, 62).

${ }^{23}$ А. И. Андреев, "Рецензия на книгу: Н. А. Воскресенский. Законодательные акты Петра І. Акты о высших государственных установлениях. Т. І. Редакции и проекты законов, заметки, доклады, доношения, челобитья и иностранные источники / под ред. и с предисл. Б. И. Сыромятникова. Москва-Ленинград, 1945," Вопросы истории, 2-3 (1946), 141. (A. I. Andreev, "Retsenziia na knigu: N. A. Voskresenskii. Zakonodatelnye akty Petra I. Akty o vysshikh gosudarstvennykh ustanovleniiakh. T. I. Redaktcii i proekty zakonov, zametki, doklady, donosheniia, chelobitia i inostrannye istochniki / pod red. i s predisl. B. I. Syromiatnikova. Moscow-Leningrad, 1945," Voprosy istorii, 2-3 (1946), 141).

${ }^{24}$ См. этот акт в рукописи Н. А. Воскресенского: Научный архив Института российской истории Российской академии наук, ф. “А”, оп. 1, д. 90, л. 130-132. (Nauchnyi arkhiv Instituta rossiiskoi istorii Rossiiskoi akademii nauk, f. "A", op. 1, d. 90, 1. 130-132).

25 “Приемы научного издания памятников,” 62. (“Priemy nauchnogo izdaniia pamiatnikov,” 62).

${ }^{26}$ Н. А. Воскресенский, Законодательные акты Петра I. Редакции и проекты законов, заметки, доклады, доношения, челобитья и иностранные источники. Т. І. Акты о высших государственных установлениях (Москва-Ленинград: АН СССР, 1945), 19. (N. A. Voskresenskii, Zakonodatel'nye akty Petra I. Redaktsii i proekty zakonov, zametki, doklady, donosheniia, chelobit'ia i inostrannye istochniki. T. I. Akty o vysshikh gosudarstvennykh ustanovleniiakh (Moscow-Leningrad: AN SSSR, 1945), 19). 
воспроизводства первой редакции с помещением разночтений в текстуальные примечания, поступили и с актами № 36, 223, 118 (415) (с. 30, 285, 556). На наш взгляд, получившаяся публикация менее удобна по сравнению с тем, как ее планировал Н. А. Воскресенский. При этом речь, в общем-то, идет о довольно небольшом количестве актов, для которых следовало напечатать первые, черновые редакции. С учетом того, что в книгу вошло около боо актов, это не привело бы к какому-то существенному росту объема публикации.

3. Н. А. Воскресенский считал, что его издание “должно сохранить и воспроизвести все особенности языка той эпохи.” По этой причине он приводил акты “с сохранением всех поправок и с полной точностью орфографии подлинника.” Им было сделано “только два отступления: введены прописные буквы и расставлены знаки препинания согласно требованиям современной грамматики." ${ }^{27}$ Как результат, Воскресенский сохранял при передаче текста вышедшие из употребления буквы дореволюционного алфавита, равно как и имеющиеся сокращения, не раскрывая их. За это он был также раскритикован А. И. Андреевым. Последний, заметив, что археографы “различают приемы воспроизведения текстов в интересах филологов и историков,” отметил, что “для работ последних лет нет надобности в той буквальной точности воспроизведения текста, к которой стремится Н. А. Воскресенский.” ${ }^{28}$ В издании 2020 г. в духе рекомендации Андреева тексты актов переданы гражданским алфавитом с заменой вышедших из употребления букв современными. Кроме того, в ряде случаев раскрыты сокращения с применением квадратных скобок, т.е. “д[ень]” вместо “д.” Правда, раскрытие сокращений было произведено непоследовательно, так что в одних актах оно есть (№ 74, 75, 76, 81, 92 и др.), а в других - нет (№ 122, 125, 131, 134 и др.).

4. В связи с упомянутыми выше квадратными скобками важно указать еще на следующее правило Н. А. Воскресенского, которое он прямо прописал во введении ко II тому: “Тексты, зачеркнутые в процессе законодательной работы, воспроизводятся в тексте в круглых скобках; квадратные же скобки, согласно с принятыми приемами времени Петра I, включают в себя тексты пояснений, вставки, примеры и т.п.; они оставлены там, где употреблены в подлинных рукописях. Текст, напечатанный разрядкой, обозначает принадлежность его самому Петру I; в сравнительно редких случаях разрядкой набраны вставки в основной текст законопроекта, сделанные другой рукой” (с. 6). Однако в издании 2020 г., вопреки таким предписаниям, оригинальные квадратные скобки петровского времени заменили на современные круглые, напечатав, например, “(или правил)” вместо “[или правил],” а квадратные использовали, как выше отмечалось, для раскрытия сокращений. К сожалению, такая рокировка не оговаривается, так что читатель уже по ходу работы с актами должен понять, что скобки используются не так, как это указывается Воскресенским во введении ко второму тому.

5. С вышеизложенным связана другая проблема. Дело в том, что Н. А. Воскресенский, используя круглые скобки для обозначения зачеркнутых слов в тексте, а разрядку - для вставок, пытался особым образом показать процесс выработки текста законодательного акта. ${ }^{29}$ Однако в издании 2020 г. отказались от такого подхода, поместив все зачеркнутые слова в текстуальные примечания.

\footnotetext{
${ }^{27}$ Воскресенский, Законодательные акты Петра I, 21. (Voskresenskii, Zakonodatelnye akty Petra I, 21).

${ }^{28}$ Андреев, “Рецензия на книгу,” 141. (Andreev, “Retsenziia na knigu,” 141).

${ }^{29}$ См., например, в первом томе: Воскресенский, Законодательные акты Петра I, 469. (Voskresenskii, Zakonodatelnye akty Petra I, 469).
} 
Для наглядности обратимся к Регламенту Главного магистрата и приведем небольшой фрагмент VII главы его первой - A - редакции, как он воспроизведен в издании 2020 г. (с. 222):

${ }^{330}$ Втораго состояния ${ }^{331}$ суть: || банкиры ${ }^{332}$, которые дают на векселя денги ${ }^{333}$, знатные торговые ${ }^{334}$, также лавашники ${ }^{335}$, которые шелковыми $\mathbf{u}^{336}$ шерстеными ${ }^{337}$ товарами торгуют, аптекари, шиперы ${ }^{338}$ купеческих кораблей ${ }^{339}$, золотари и серебряники, живописцы, лекари и сим подобные, которые все ${ }^{340}$ первое или болшее гилде (или ${ }^{341}$ собрание $^{342}$ ) гражданства сочиняют и от другаго подлаго гражданства 343 через никоторые $\mathrm{e}^{344}$ привилегии ${ }^{345}$ и преимущества отменны. ${ }^{346}$

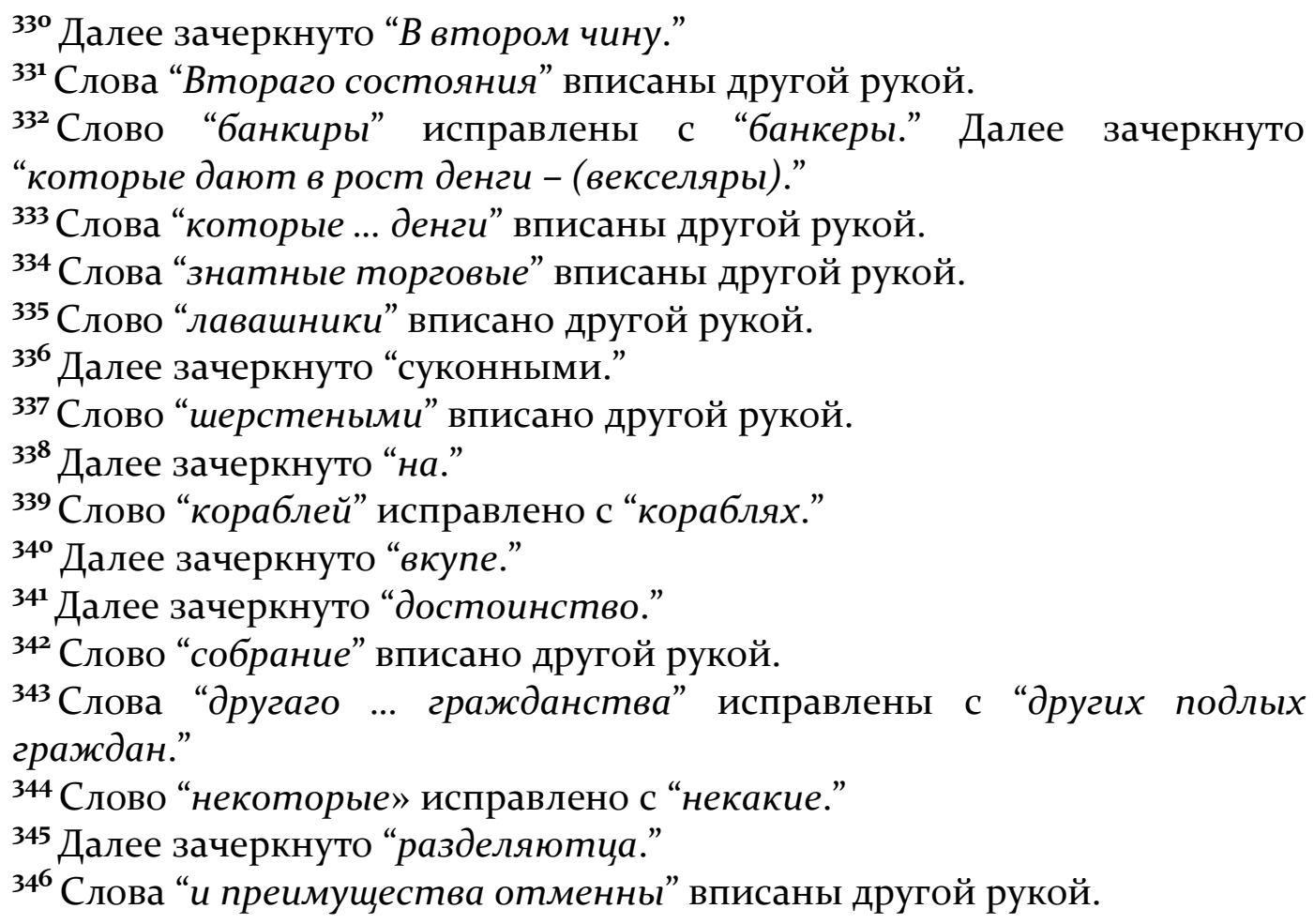

Что примечательно, во введении к публикации Регламента Главного магистрата Н. А. Воскресенский дополнительно оговорил следующие правила: “Текст подлинника, зачеркнутый при исправлении, берется нами в простые скобки, написанный вместо него печатается разрядкой” (с. 215). Однако, как видно из приведенного текста, эти правила в издании 2020 г. были изменены.

Теперь приведем этот же фрагмент, как он должен был бы быть опубликован по правилам Н. А. Воскресенского и, собственно, как он и был воспроизведен в рукописи, ${ }^{30}$ которая легла в основу издания 2020 г.:

(В второмъ чину) Втораго состояния суть:| банк(иры)еры, (которые даютъ в ростъ денги - [вексъляры]), которые дают ъ на вексьл денги; (великие купцы) знатные торговые, также лавашники, которые шелковыми i (суконными) шерстеными товарами торгуютъ, аптекари, шиперы (на) купеческих корабл(ях)ей , золотари и серебрянники, живописцы, лькари и симъ подобные, которые всь (вкупе) первое или болшее гильде [или (достоинство) с обрание] гражданства сочиняютъ и от друг(их)а го под(лыхъ)а го

\footnotetext{
${ }^{30}$ Научный архив Института российской истории Российской академии наук, ф. “А”, оп. 1, д. 9оа, л. 40. (Nauchnyi arkhiv Instituta rossiiskoi istorii Rossiiskoi akademii nauk, f. "A", op. 1, d. 9oa, 1. 40).
} 
граждан(ъ)с т в а черезъ нек(акие)о торые привилегиі (раздъляютца)

і преимуществы отмьнны .

Сравнивая два этих фрагмента, убеждаешься в справедливости замечания Д. О. Серова, что приемы Н. А. Воскресенского “ни в коей мере не были ни абсурдными, ни антинаучными” (с. LXXII-LXXIII). Действительно, если текст подвергался относительно неинтенсивной правке, то исправления удобно будет поместить в текстуальные примечания. Однако Воскресенский столкнулся с проектами законодательных актов с высокой плотностью правок. И, как видно из издания 2020 г., если прибегнуть к текстуальным примечаниям, то даже воспроизводство небольшого фрагмента требует большого массива таких примечаний, что весьма неудобно, не говоря об экономии печатных знаков. Предложенные Воскресенским правила позволяют без громоздких текстуальных примечаний точно воспроизвести правки в тексте, при этом сохранив динамику рукописного оригинала и затратив примерно в два раза меньше знаков, чем если бы это было с примечаниями. Касательно же первой - A - редакции заметим, что в этих же подстрочных примечаниях - теперь уже в соответствии с замыслом Воскресенского воспроизведены и разночтения со второй - Б - редакцией, что не добавляет простоты в восприятии текста.

6. Укажем и на проблему с библиографическим описанием настоящего издания. На титуле первого тома, т.е. прижизненного издания 1945 г., фамилия Воскресенского указана над заглавием Законодательные акты Петра I. Причина, почему Воскресенский был обозначен у этой книги именно как автор, а не убран под одну косую черту как скромный составитель, была объяснена редактором первого тома Б. И. Сыромятниковым: “В основе труда (Воскресенского. - М. К.) [...] лежит публикация текстов законодательных актов Петра I, но Н. А. Воскресенский подает их в таком виде, в таком ансамбле актового материала, что его 'издание' превращается в настоящее исследование, вскрывающее перед читателем историю рождения каждого законодательного акта петровской эпохи.” В связи с этим Сыромятников подчеркивал, что Воскресенский “внес в свою работу и элемент систематизации материала, и дал не просто тексты законодательных актов, но историю их образования. А это уже работа исследовательского характера." ${ }^{11}$ Правда, такой подход, например, не удовлетворил А. И. Андреева, который критиковал Воскресенского за то, что он в своем издании смешал две разных задачи: “исследование происхождения акта и его издание."32 Публикаторы II-III томов, специально не оговаривая причин, решили изменить библиографическое описание, так что на титульном листе фамилия Воскресенского переместилась под заглавие Законодательные акты Петра I. Более того, перед его фамилией также появилось слово “Составитель.” Помимо прочего, это означает, что теперь в библиотеках первый том будет стоять на полке с литерой “В,” а второй - с литерой “3.”

7. Отметим, что Н. А. Воскресенский не сопровождал свою публикацию смысловыми комментариями. Однако научный редактор II-III тома в своих примечаниях посчитал за нужное в некоторых случаях прокомментировать

\footnotetext{
${ }^{31}$ Б. И. Сыромятников, “От редактора,” в Н. А. Воскресенский, Законодательные акты Петра I, XXXIV-XXXV. (B. I. Syromiatnikov, "Ot redaktora," v N. A. Voskresenskii, Zakonodatelnye akty Petra I, XXXIV-XXXV).

${ }^{32}$ Андреев, “Рецензия на книгу," 136. (Andreev, "Retsenziia na knigu," 136).
} 
упоминаемых в источниках персон. Безусловно, это упрощает работу с данным изданием. ${ }^{33}$

Таким образом, настоящее издание не передает во всей полноте труда Н. А. Воскресенского как археографа. Определенная логика у современных редакторских правок есть, и она фактически идет в русле критики А. И. Андреева. Правда, такая связь носит опосредованный характер. Андреев стоял у истоков разработки приемов публикации источников в XX в. Их продолжением явились Правила издания исторических документов в СССР 1990 г., в логике которых в акты Н. А. Воскресенского и были внесены правки в части употребления букв дореволюционного алфавита, использования круглых и квадратных скобок и помещения всех зачеркиваний в текстуальные примечания.

На наш взгляд, таких правок не следовало вносить и опубликовать акты по тем правилам, которые выработал Н. А. Воскресенский. Во-первых, все же стоило помнить о праве Воскресенского как автора на неприкосновенность его произведения. Во-вторых, Законодательные акты Петра I представляют самостоятельный интерес как памятник археографической мысли первой половины XX в. Однако, к сожалению, в итоге публикация II-III томов состоялась и не по правилам Воскресенского, и не по Правилам издания исторических документов в СССР 1990 г., а по какому-то их прямо неоговоренному гибриду. ${ }^{34}$

Впрочем, основную часть историков, которая будет обращаться в своих штудиях к Законодательным актам Петра I Н. А. Воскресенского, едва ли будут интересовать такие эдиционно-археографические нюансы. В конце концов, археография - это “всего лишь” вспомогательная историческая дисциплина. Так что перейдем собственно к содержанию II-III томов.

Второй том, озаглавленный “Акты об общественных классах," состоит из семи частей. Первая - "Указы Петра I об основаниях дворянского землевладения” (с. 922), где ключевое место занимает знаменитый указ о единонаследии от 14 апреля 1714 г. Вторая часть - “Табель о рангах и акты о государственной службе” (с. 24-118), где, как понятно из ее названия, ключевое место отведено Табели о рангах 1722 г. и связанным с ней законоподготовительным материалам. По замыслу Воскресенского, именно в этих частях им представлены “законодательные акты, относящиеся к дворянству, его землевладельческим правам, положению в государстве, военной и гражданской его службе” (с. 2). Однако приводимые им в этих разделах акты как раз показывают, как непросто обстояло дело с собственно дворянским законодательством при Петре I. Так, Воскресенский публикует приговор Берг-коллегии от 23 декабря 1720 г., подтверждавший, что нормы указа о единонаследии 1714 г. распространяются на завещание заводчика Н. А. Демидова, который не имел дворянства (№ 16, с. 18-19). Понятно, что указ о единонаследии прежде всего регулировал дворянское землевладение. Тем не менее, упоминание в нормативной части указа “дворов и лавок” показывало, что его действие могло касаться и посадских, как раз владевших дворами и лавками. Далее, Табель о рангах

\footnotetext{
33 В одном из комментариев допущена небольшая ошибка. В нем написано, что Ф. Б. Еверлаков покончил с собой в Тобольске в 1723 г. (с. 594, прим. 103). Однако Еверлаков все же покончил с собой, находясь при строительстве Исетского завода - будущего Екатеринбурга (В. Геннин, Уральская переписка с Петром I и Екатериной I, авт. вступ. ст. и комм., сост. М. О. Акишин (Екатеринбург: БКИ, 1995), 96). (V. Gennin, Uralskaia perepiska s Petrom I i Ekaterinoi I, avt. vstup. st. i komm. sost. M. O. Akishin (Ekaterinburg: BKI, 1995), 96).

34 Например, при исключении в публикации букв гражданского алфавита, вышедших из употребления, не были расставлены мягкие знаки по правилам современного правописания.
} 
регулировала, прежде всего, именно государственную службу, на которой состояли и многочисленные подьячие-недворяне. Таким образом, этот раздел показывает, что, собственно, в сословном дворянском законодательстве при Петре делались только первые шаги. В конце концов, только в петровское время правящий наследственный землевладельческий класс, т.н. боярство и дворянство Московского государство, стал именовать себя шляхетством или благородным дворянством, так что создание ключевых актов дворянского законодательства было еще делом будущего.

Третья часть отведена “Актам о крестьянах" (с. 120-202), при этом немалую их часть составляют нормативные акты, связанные с введением подушной подати. Посвоему это также весьма показательно: крестьянское население интересовало правительство, прежде всего, как источник ресурсов в виде налогов и иных повинностей.

Четвертая часть - это “Акты об управлении городов и о горожанах” (с. 205-320). В ней Н. А. Воскресенский основной акцент сделал на городскую реформу второй половины царствования Петра, которая началась с конца 1710-х гг., и главным актом которой стал Регламент Главного магистрата, опубликованный Воскресенском с учетом всех его редакций (с. 215-278). Соответственно, если для 1718-1724 гг. им опубликовано 28 актов, то для 1698-1715 гг. - 17, из которых 11 относятся к 1700 г. Это показывает, что Воскресенский в своей публикации делал акцент, прежде всего, на законотворчество самого Петра I, которого лавры законодателя стали активно интересовать примерно после 1715 г. Как результат, нормативные акты Правительствующего Сената 1710-х гг., которые также касались и городского населения и с которыми можно ознакомиться в незавершенном дореволюционном издании “Доклады и приговоры, состоявшиеся в Правительствующем Сенате в царствование Петра Великого" (публикация доведена по июль 1716 г.).

Пятая, шестая и седьмая части второго тома отведены нормативным актам, связанным с политикой по отношению к православной церкви. При этом в пятой “Акты об управлении православной церковью и о духовенстве” (с. 322-346) собраны документы по 1720 г., т.е. до начала работы над регламентом Синода, а в шестой, названной "Регламент Духовной коллегии" (с. 349-423), помещены материалы, связанные с этим регламентом и иные документы до конца 1723 г. Соответственно, в части “Определение о монастырях, от 31 января 1724 года" (с. 425450) помещены материалы, связанные с этим законом, а также нормативные акты о православной церкви с января по декабрь 1724 г.

В третьем томе “Акты о промышленности и торговле” Н. А. Воскресенский опубликовал акты о промышленности с начала 1720 г. по начало 1725 г., а также Берг-привилегию от 10 декабря 1719 г. и связанное с ней описание шведской Бергколлегии 1718 г. (с. 454-718). Из крупных законодательных актов петровской эпохи наибольший интерес в этом томе представляет публикация Регламента Мануфактур-коллегии в трех редакциях (с. 631-652).

Итак, благодаря этой публикации историки получают в свое распоряжение огромный массив источников о внутренней политике Петра I, которые Н. A. Воскресенский выявил в архивных фондах, хранящихся в настоящее время в Российском государственном архиве древних актов, Российском государственном военно-историческом архиве (Москва), Российском государственном историческом архиве и Архиве Военно-исторического музея артиллерии, инженерных войск, и войск связи (Санкт-Петербург), а затем систематизировал их по тематике. При этом для понимания законотворчества петровского времени большое значение имеет 
публикация ключевых законодательных актов - указа о единонаследии 1714 г., Регламента Духовной коллегии 1720 г., Регламента Главного магистрата 1721 г., Табели о рангах 1722 г., Регламента Мануфактур-коллегии 1723 г. и некоторых других - в ансамбле законоподготовительных материалов.

В то же время следует отметить, что публикация Н. А. Воскресенского с точки зрения полноты не является исчерпывающей и не избавляет исследователей как от необходимости обращаться к иным изданиям, включая “Полное собрание законов Российской империи”, так и продолжать архивные поиски. Приведу следующие примеры, связанные с научными изысканиями автора настоящих строк. Так, в публикации Воскресенского отсутствует имеющийся в ПСЗ важный сенатский указ от 8 ноября 1723 г. "О фабрикантах, которым по службам и податям следует быть в ведомстве Магистрата," 35 а также проект В. Н. Татищева о медеплавильных заводах с собственноручными резолюциями Петра I от 13 февраля 1724 г., опубликованный еще в 1873 г. ${ }^{36}$

Если же говорить о неопубликованных нормативных документах, то приведем такой пример. 10 мая 1723 г. Петр I распорядился: “когда от его величества которой колегии или канцелярии присланы будут письменые, или по словесным его величества приказом записаны указы, и о тех указех немедленно для ведома объявлять в Сенат, чтоб за неведением от таких указех не происходило в делех помешательства." В связи с этим 5 июля 1723 г. Мануфактур-коллегия направила в Сенат четыре таких указа, один из которых имел для меркантилистской промышленной политики Петра I программное значение. Этот указ, подписанный в Астрахани 13 июля 1722 г., повелевал Мануфактур-коллегии

прилежное радение иметь, дабы разсмотреть все товары, которые идут в Росийские государства деланные и материалы, и о них такое расположение учинить: о первых трудитца, чтоб делать дома все, которых материи в сем государстве найтися могут, и когда умножатца, что довольно оных будет, тот час доносить Сенату, чтоб положили пошлину тяжелую на оной, дабы не могли вывозить. На другие искать, про которые не ведаем, таким образом: розослать по нескольку той материи по всем городам, дабы роздавали по штучке всякого чина людем, кто похощет, обещая дать деньги, кто такую материю сыщет. ${ }^{37}$

Воскресенским же был опубликован только указ Петра от 5 ноября 1723 г., изданный в дополнение к указу от 13 июля 1722 г., где монарх развивал свои меркантилистские идеи (№ 178 (511), с. 610-611).

Кроме того, уместно будет вспомнить и критические пассажи А. И. Андреева о случайном подборе документов у Н. А. Воскресенского. ${ }^{38}$ Действительно, хотя сборник называется Законодательные акты Петра I, в нем можно найди документы, которые практически не имеют отношения к законодательству и - шире

\footnotetext{
${ }^{35}$ ПСЗ, т. 7, № 4352, 154-155. (PSZ, t. 7, № 4352, 154-155).

36 “13 февраля 1724 г. Высочайшия резолюции на донесении В. Н. Татищева, об устройстве и размножении в Сибири медных заводов” в Сборник Русскаго историческаго общества (СанктПетербург: Тип. 2-го Отд-ния Собств. Е.И.В. Канцелярии, 1873), т. 11, 539-544. ("13 fevralia 1724 g. Vysochaishiia rezoliutsii na donesenii V.N. Tatishcheva, ob ustroistve i razmnozhenii v Sibiri mednykh zavodov" v Sbornik Russkago istoricheskago obshchestva (St. Petersburg: Tip. 2-go Otd-niia Sobstv. E.I.V. Kantseliarii, 1873), t. 11, 539-544).

${ }^{37}$ Российский государственный архив древних актов, ф. 248, д. 7оo, л. 11, 14. (Russian State Archive of Ancient Acts, f. 248, d. 700, 1. 11, 14).

${ }^{38}$ Андреев, “Рецензия на книгу,” 139. (Andreev, "Retsenziia na knigu," 139).
} 
- правотворчеству. Например, Воскресенский включил в третий том “Постановление Берг-коллегии о производстве ученика Дементия Иванова в подмастерья Монетного двора с присвоением установленной зарплаты, от 9 июля 1722 года" (№ 125 (458), с. 560-561). Возникает вопрос: почему в Законодательных aктах Петра I помещен документ, посвященный в общем-то совершенно частному с точки зрения законодательства вопросу о назначении ученика подмастерьем? Или вот Воскресенский поместил в третьем томе более тридцати довольно объемных донесений В. И. Геннина 1722-1724 гг. в столицу об управлении уральскими заводами. Безусловно, это интересный источник для истории промышленной политики. Однако, если говорить именно о законодательстве, вместо них более уместными были бы указы Берг-коллегии за это время, пусть они в строгом юридическом значении были актами не законодательными, а подзаконными.

Что важно, публикация сопровождается "Указателем центральных государственных учреждений” (с. 723-733) и “Именным указателем” (с. 734-761), в которые включена и информация по первому тому Законодательных актов Петра I 1945 г.

В качестве своеобразного послесловия к публикации II-III томов помещен небольшой и проникновенный очерк Д. А. Редина, посвященный памяти Д. О. Серова (с. 719-722).

В заключение специально подчеркну, что высказанные в настоящей рецензии замечания никоим образом не умаляют большого труда, сделанного Н. A. Воскресенским, а также публикаторами II-III томов его Законодательных актов Петра I. Без всяких сомнений это издание является долгожданным и знаменательным событием, которого, к великому сожалению, не дождался Д. О. Серов. Наши замечания призваны показать, что даже после выхода таких фундаментальных публикаций еще остается пространство как для научного поиска, так и для совершенствования приемов публикации источников. 